\section{ON THE EARTHQUAKES AT AGRAM IN 1880-81}

[ $\mathrm{T}$ our request Prof. Szabo, Professor of Geology and Mineralogy in the University of Budapest, has prepared for the pages of NATURE the following account of the recent earthquakes at Agram. This account is a thoroughly reliable one, as it is drawn up from information obtained from Dr. von Hantken, the Director of the Hungarian Geological Survey, and Mr. Schafarrik (Prof. Szabo's assistant), both of whom were officially deputed to visit the district and inquire into the whole of the facts.]

On November 9, I880, at $7 \mathrm{~h}$. $33 \mathrm{~m}$. 53s., a very violent earthquake passed over the south-western quarter of Hungary and also Bosnia and Herzegovina. The limits of this large territory are approximately as follows :West, the peninsula of Istria and the town of Trieste; north, Vienna and Gōdöllö (north-east from Budapest); east, the flat lands between the Danube and the Theiss; and south it reached far beyond Serajewo, because the earthquake was felt in this town also very strongly. It is said by some that the earthquake was even observed in Budweis (in Bohemia) and in Debreczen (east northeast from Budapest). This territory is approximately equal to a circle, the radius of which is forty geographical miles long, and therefore its area is nearly 5000 square miles. From all information received up to the present time it may be asserted that the earthquake was not equally felt over the whole territory, but mostly in the centre of the circle-in the environs of Agram, where the damage occasioned was considerable.

According to the testimony of trusty witnesses the earthquake began on the day mentioned above with a strong shock in an upward direction, which was accompanied simultaneously with a perceptible and loud subterranean noise; this was followed by a subsidence; then came a perpendicular shock from below; and lastly came an oscillatory movement of the earth in an eastsouth-east to west-north-west-direction. This movement, which lasted nearly ten seconds, was so intense that in the town of Agram not only all the larger public buildings, but with few exceptions every dwelling-house, was damaged more or less.

One peculiarity of this first shock is that not only were objects of small weight removed out of their original positions, and this was especially the case with objects standing on a flat surface, but it also produced a certain rotatory motion upon them (contrary to the hand of a watch); even some trustworthy witnesses affirm that the first shock had a rotatory effect on them.

Chimneys are the objects which are the most easily damaged by earthquakes, and so in Agram there was scarcely a chimney to be seen after the earthquake which had not been either cracked or entirely ruined. The number of fallen chimneys amounts to nearly a thousand. An enormous amount of damage was also done to the roofs of houses; one could see from the roof-tiles placed on laths that they had been shaken by the oscillation, and were partially broken and fallen down, especially those which were situated towards the east or west. All this happened in the morning when the streets were mostly crowded with people, and one must be astonished indeed that the great quantity of falling masonry, parts of walls, stone cornices, huge beams of wood, and pieces of broken glasses, \&c., did not hurt more people; altogether only twelve were severely wounded (broken arms, hands, feet, head wounds, \&c.), but only in two cases did the injuries prove fatal; about twenty suffered slight contusions. In the surrounding country three men died, and some suffered from various injuries.

Among the public buildings and the larger dwellinghouses in Agram not one has actually fallen to ruin, but the number of those houses, whose outward walls were obliged to be supported by long beams on every side, is considerable; much more terrible, however, is the view of destruction inside the buildings; the mortar from the walls of the rooms is for the greatest part fallen down, and the thinner walls have been shaken so much that some of them are totally fallen to ruin. About twelve buildings were so ruined by the earthquake that it was necessary to forbid their reconstruction, and the Senate of the town found itself compelled to order their entire demolition. Here is the corner house belonging to $\mathrm{Mr}$. Priester, with two storeys facing the Marie-Valerie Street and Jellacsics Square, whose western frontal wall has separated itself from the other parts of the house, and is entirely bent towards the Marie-Valerie Street; the house of Mrs. Zorgách in the Petrijani Street is ruined and must be demolished; the building of the Military Academy in Ujlak has been a real and sad ruin. In the upper part of the town the following edifices are designated to be demolished:-Br. Ozegovich's house, the Mednyanszka Barracks, a certain part of the military "General-Commando" building, \&c. The number of those buildings which have been rendered uninhabitable by the earthquake is great, but with great difficulty-by using iron braces - they can be renewed. To these buildings belong the cathedral, which is erected in the broad square courtyard of the archbishop's palace. In this cathedral the vault of the sanctuary has fallen in and has covered the high altar and the space before it with fragments of wall and rubbish ; further, a part of the vault just before the organ and a little to the right of the entrance has fallen down in the centre nave; in the side nave a very heavy horizontally-placed buttress split, fell down, and broke through the tombs where the coffin of a canon was; besides these more striking damages the main wall was split in several parts. The archbishop's palace itself has been damaged to such an extent that the archbishop and the canons were obliged to leave their apartments for a long time. In the same manner the Franciscan and St. Mark's Churches were also damaged. One can also add among the others St. Catharine's Church, which has been sadly damaged, as also the edifices of the University and of the "Realschule," and many other private houses. The high chimneys of the gas-factory and of Grator's brick-kiln were only partially damaged at the upper part.

After these come those houses which, though they were very greatly damaged, yet the people were not obliged to quit them; and lastly follows the great number of those buildings which sustained only smaller damages (for instance, little rifts near the windows or along the corners of the walls, through mortar, \&c., falling down). The proportion between the number of the edifices which became uninhabitable and had to be demolished, in comparison with those which were damaged in a greater degree and those which were slightly damaged, is about I : I : 4. This arithmetical proportion nevertheless cannot at all express the damage that happened, because among the two first categories are the most valuable buildings, viz. the churches, barracks, the largest and newest houses, while the mass of the third category consists of small low buildings; one must attend to the above descriptions because it is impossible to set strict bounds between the single categories, for there were many houses whose ground-floors were totally free from chinks, the first- and second-floors already showed gradually more chinks in the walls, while the third-floor presented a terrible picture of destruction. The damage to edifices caused by earthquakes depends on their solidity, on their height, and on their situation. As regards the solidity, they found that the weaker the walls were, and where iron braces were not applied, the more were the buildings damaged; as regards the height, on the occasion of this earthquake it was observed that the secondfloor was more damaged than the first, and the third more than the second; and finally as to the situation, 
there are some remarkable examples, houses forming south-east and north-west corners were exceedingly damaged, viz. south-east was the direction where the first shock came from.

In the environs of Agram the earthquake appeared with no less strength than in the town itself, but the damage to the surrounding country is not so general, because here are the peasants' cottages all built of wood. Here therefore only the churches, the parsons' houses, schools, castles, and gentlemen's private houses were the objects on which the earthquake left visible marks.

All the buildings of any strength in the villages which are situated at the south-east slope of the mountain called Sleme, north from Agram, were damaged in a more or in a less degree; there is for instance the well-known place for pilgrimages, Remete (5 km. north of Agram), where the walls of the church, which is ornamented inwardly with very beautiful frescoes, and of the steeple are strongly gaped in all directions, while the vaulted roof of the nave is totally fallen down; so is also the residence of the parson; the damage caused in these two edifices amounts, according to an official valuation, to 38,000 florins. In Grancsina ( $7 \mathrm{~km}$. north-east from Agram) the steeple, falling down in an easterly direction; broke through the roof and the vault of the church, so that now one can see only the four very ruptured walls. On the other side of the mountain Sleme, in a certain part of Croatia named Zagoria, many castles were ruined.

The circle, where the earthquake caused the heaviest losses has approximately the following bounds:- Southwest, Karlstadt ; west, Landstrass, Gurkfeld ; north-north west, Rohitsch; north, Warasdin, Csáktornya ; northeast, Kaproncza (Kopreinitz); east, Belovár; south-east, Sziszek, which corresponds to a territory of about 120 square miles; the centre of this circle was the place where the first shock emanated from. The data kept in the surrounding parts relative to the direction and the greatest intensity of the shock indicate the territory which lies to south-east from Agram, and forms the alluvium of the River Save as the starting-point of the whole phenomenon. Here the crevice in the earth appeared also, caused by the strongly-oscillated motion. A little to the east from the village of Resnik (east-south-east from Agram) was the crevice in the alluvium of the Save. It was 5 kilometres long, and had several interruptions, and extended in a southeast direction, from which here and there some smaller crevices radiated. This chief crevice, which continued through the Save as far as the village of Scitarjevo, showed in some places a few days after the earthquake openings one to two feet broad, but for the most part the crevice was filled with bluish alluvial sand, which was forced out, mixed with water by the opening and closing of the crevice being formed by the oscillation of the soil, the water forcing its way through this dense pulp, produced by its upheaval those small flat craters which many people are inclined to declare volcanoes of mud. The dimension of these small craters is very variable; their diameters differ between 2 and $75 \mathrm{c} . \mathrm{m}$., their height $\mathrm{I}$ to $30 \mathrm{c.m}$.; and, calculating from these numbers the cubic contents of the largest flat cone, we receive nearly 0.5 cubic metres; this little quantity of the out-pressed material is enough to exclude the hypothesis that these cones were the result "of a slow action for some hours." If hydro-sulphuric gas was present during this phenomenon, as some believe, it is not known, because we want positive and trusty evidence on this point. Moreover it is not impossible that there should be an appearance of small quantities of hydrosulphuric gas dissolved in the water of an alluvial slimy soil, because such water generally contains decaying substances and finely-dispersed sulphates, but one can in no case suppose that a great quantity of hydrosulphuric gas would have produced the crevices and ejected the sand mixed with water.

Beyond this territory of 120 square miles the earthquake was felt with a gradually diminishing strength, and in many places the motion was so weak that a great many of the inhabitants did not remark it. Among these can be mentioned Fiume, where they felt only a very slight shock; then Budapest and Vienna, where only one or two became attentive to this phenomenon.

Beyond the territory of 120 square miles, where they suffered the strongest shocks, there are yet sone environs, though far enough from the centre, where destruction also happened, for instance in Styria, and in Hungary, in the neighbourhood of Pécs (Fünfkirchen). To explain the connection of these cases with the entire phenomenon deeper researches must be made.

It remains to communicate shortly the statics of the earthquake.

1. November 9, at 7 h. $33 \mathrm{~m}$. 53s. in the morning, the first shock enduring io seconds with a subterranean noise. This one has caused all the damage.

2. November 9 , at $7 \mathrm{~h} .37 \mathrm{~m}$. in the morning: an oscillatory motion without a noise.

3. November 9 , at $8 \mathrm{~h} .27 \mathrm{~m}$. $55 \mathrm{~s}$. in the morning : slight motion.

4. November 9, at 10 h. $50 \mathrm{~m}$. in the evening : very slight motion.

5. November 10, at $6 \mathrm{~h}$. in the morning: very slight motion.

6. November II, at $1 \mathrm{Ih} .26 \mathrm{~m}$. in the forenoon: a strong oscillation, which effected some damage.

7. November 16 , at $12 \mathrm{~h}$. $4 \mathrm{~m}$. in the morning: a sufficiently strong shock accompanied with a dull noise.

8. November 16 , at $12 \mathrm{~h} .44 \mathrm{~m}$. ?

$\left.\begin{array}{rrr}9 . & \quad " & \text { 12h. } 49 \mathrm{~m} . \\ \text { ro. } & \text { 1h. } 9 \mathrm{~m} .\end{array}\right\}$ in the morning :

II. " " $"$ 4h. $24 \mathrm{~m}$.

weak oscillations," of which only the last had a little more strength than the others.

So it lasted continually during December. Even in this year (188I) in January and February feeble shocks recurred after longer interruptions; the last shock was recorded in the newspapers from March 4

Budapest, March 18

THE ST. PETERSBURG DYNAMITE MINE

$T H E$ following account of the mine recently discovered in St. Petersburg, extracted from Russian sources, gives a remarkable picture of the state of society in the empire, where able chemists and expert miners can be found to engage in such desperate undertakings.

It appears from a sketch-plan which accompanied the translation put into our hands, that the mine extended from one side of Malaya Sadobaya Street to the centre of the roadway; the total length of the mine gallery being fifteen paces, the street must be thirty paces, say seventyfive feet wide.

The gallery terminated in a chamber about double its diameter, and in this was found the charge contained in a case twenty-two inches long and eight inches diameter, weighing sixty-five pounds, and beside this a glass jar contained about thirty pounds more of the explosive substance, apparently an excess quantity over that required for the actual explosion. The explosive consisted of a species of dynamite made by mixing nitro-glycerine with powdered charcoal. This is more powerful in its effects than the ordinary substance, in which an inert body, generally a soft infusorial earth, takes the place of the charcoal. The description of the fuse, as contained in the Russian account, is very obscure, but so far as can be made out it would appear to have consisted of a wide heavy glass tube containing an explosive, described some time back in NAJURE, and prepared by mixing nitro-glycerine with about Io per cent. of guncotton, the result being a very explosive substance of a partially gelatinous character. In the midst of this, and 